\title{
METHODS
}

\section{A method for valuing global ecosystem services}

\author{
Anne M. Alexander ${ }^{\mathrm{a}, *}$, John A. List ${ }^{\mathrm{b}}$, Michael Margolis ${ }^{\mathrm{a}}$, Ralph C. d'Arge ${ }^{\mathrm{a}}$ \\ a Department of Economics and Finance, University of Wyoming, Laramie, WY 82071-3985, USA \\ ${ }^{\mathrm{b}}$ Department of Economics, University of Central Florida, Orlando, FL 32816-1400, USA
}

Received 6 January 1997; received in revised form 22 September 1997; accepted 13 November 1997

\begin{abstract}
The goal of this paper is to provide an investigation of several approaches to valuing ecosystem services and to contribute additional techniques which may be used in evaluating 'green' GDP accounts. Our estimates focus on the ecosystem as a productive economic input, not a stock which is depreciated or depleted over time; as such, it differs with other concepts more frequently employed in green GDP accounting. Most of our results are derived from the analytical fiction that a single owner of the biosphere establishes a market for all ecological resources. This monopolist then appropriates all rents from the human population. The maximum amount the monopolist charges is first assumed to be world gross product less the global human subsistence level. In addition, we examine the excess rents available in factor markets using the assumption of weak complementarity between factor inputs and ecosystem services. We also provide more conservative estimates of the value of ecosystem services by investigating the sustainable price the monopolist could charge the global population and by exploring the effects of compensating wage differentials and a non-monopolist owner of the ecosystem. (C) 1998 Elsevier Science B.V. All rights reserved.
\end{abstract}

Keywords: Ecosystem services; Monopolist; Excess rents; Maximum surplus; Weak complementarity

\section{Introduction}

While it is ubiquitously acknowledged that ecosystems are essential to human existence, ecosystem services are typically unpriced or not

\footnotetext{
* Corresponding author. Fax: + 1307 7665090; e-mail: aalex@uwyo.edu
}

priced correctly at their marginal value because of a lack of private, organized markets for such services. The absence of pricing mechanisms for the ecosystem means that their contribution to our economy does not enter into most current Gross Domestic Product (GDP) accounts. Some countries such as Sweden have tried to correct for this by introducing 'green' GDP accounting. Typ- 
ically, their methods entail treating ecosystem services as a stock of inputs which are depreciated or depleted over time. This methodology does not account for the productivity of ecological inputs on which humans rely in economic pursuits. The fact that the ecosystems' value to our global economy is not recognized or measured well has broad policy implications - the omission of its value implies the importance of the ecosystem may be ignored in bottom-line policy decisions. Since the ecosystem is a quintessential ingredient for economic activity, this exclusion is grossly negligent. Moreover, when the value of ecosystem services to land, labor, and capital productivity are disregarded, these three factors are overvalued and the ecosystem slighted in its contributions to our global economy. Thus, when we speak of the value of ecosystem services in this study, we do not infer that a 'price' exists for ecosystem services (e.g. so the ecosystem can be bought and sold in the marketplace), rather, we intend to bring to light the very real economic value of the ecosystem, which to date, is glaringly ignored in current national accounting practices.

In this paper, we use neoclassical economic methods to examine several techniques of indirectly inferring a market value for ecosystem services to be included in green GDP accounts. In keeping with the spirit of GDP accounting, which enumerates the value of payments made to factors of production, the values we arrive at for ecosystem services are bounded above by gross world product. ${ }^{1}$ The amount human society is pragmatically able to pay for ecosystem services cannot exceed world product because it is all that we can afford. Our investigation hinges on this assertion. We are not attempting to set a value for each service provided by the ecosystem, but rather are seeking the maximum amount that could feasibly be paid for these services. ${ }^{2}$

\footnotetext{
${ }^{1}$ In particular, by the sum of all GDPs as currently calculated $\sim \$ 18$ trillion in 1987 (the year for which all calculations are made). If all ecosystem services were priced through markets, GDP would undoubtedly be quite different.

${ }^{2}$ A hotly debated issue is whether we should place a value on the ecosytem. Given individuals make ecosystem choices
}

Our attention is thus restricted to what Brown (1984) has called 'economic values'. ${ }^{3}$ These values are assigned by a social process influenced both by the context - chiefly markets, but also government and other collective procurement institutions - and by underlying 'held values', such as the value associated with health enjoyed due to consumption, or the beauty perceived in wild lands. Whether such economic value is an appropriate measure of a resource's contribution to welfare depends both on the legitimacy of the held values and the accuracy with which they are captured in this context. The legitimacy of held values is a notion that economists almost universally assume, or put aside as not amenable to logical analysis, but much of modern environmentalism has consisted of attempts to influence held values so that stewardship and the health of other species are weighted more heavily. As for context, we have no reason to believe that existing systems (i.e. representative government) for the purchase of collective goods correctly capture citizens' held values. By restricting our attention to economic value we place all of these problems aside.

Our methods are also sensitive to assumptions regarding the importance of ecosystem services in production and consumption processes. For example, if ecosystem services and other inputs, such as labor and capital, are readily substitutable, their value would be bounded above by the cost of such substitution. If a dollar's worth of labor services could be substituted for ten units of ecological services, the value of ecological services could not exceed $\$ 0.10$. Otherwise, labor services would be partially or completely substituted for ecological services.

The assumption we make is at the other extreme-ecological services are absolutely essential in production and consumption. Their value could therefore be as great as the surplus gener-

every day, economic agents are implicitly valuing ecosystem services daily (Costanza et al., 1997). Thus, research such as Costanza et al. (1997) and this endeavor represent first efforts to further our understanding of not only the value of all ecosystem services, but also different approaches that can be implemented to obtain this value.

${ }^{3} \mathrm{We}$ are grateful to an anonymous referee for bringing Brown's taxonomy to our attention. 
Table 1

Comparison of estimates of economic value of global ecosystem services

\begin{tabular}{llc}
\hline Type of measurement & Annual value (trillions 1987 US\$) & Percentage of 1987 world GDP \\
\hline Maximum surplus $^{\mathrm{a}}$ & 16.2 & 88 \\
Maximum sustainable surplus $^{\mathrm{a}} \mathrm{c}$ & 15.9 & 86 \\
Maximum sustainable non-monopolist surplus $^{\mathrm{b}} \mathrm{c}$ & 10.6 & 57 \\
Complementary land value $^{\mathrm{b}}$ & 0.765 & 4.25 \\
Complementary labor value $^{\mathrm{c}}$ & 7.2 & 39 \\
Total complementary value $^{\mathrm{d}}$ & 8 & 44
\end{tabular}

a 'Maximum surplus' is based on current world output in 1987 dollars. 'Maximum sustainable surplus' is based on US data and represents the fraction of sustainable world output claimable by a monopolist owner of ecological services if human capital levels globally were brought to US levels. It is converted to dollars using actual world output.

${ }^{\mathrm{b}}$ Extrapolated from US data using biomass multiplier.

${ }^{\mathrm{c}}$ Extrapolated from US data using GDP multiplier.

${ }^{\mathrm{d}}$ Sum of two previous lines rounded to nearest trillion dollars or percent.

ated in all production and consumption processes in an economy. Mäler et al. (1994) refers to this assumption as the principle of 'weak complementarity' and argues that it implies the economic value of the ecological service is capitalized in the payments made to market factors. If for example, labor and ecological services are combined to produce salmon and the entire value of this output is paid to workers, part of the wage represents the economic value of the ecosystem. Most of the calculations in this paper (which assume constant technologies intertemporally) are estimated upper bounds for the amount of payments to market factors that could be imputed to the ecosystem.

The estimates for total value of ecosystem services found by this method are bounded above by gross world product. We ignore both non-use values, such as existence value and the value of ecosystem services in non-marketed production, such as subsistence farming. This presents a sharp contrast to the procedure used by Costanza et al. (1997), who compute willingness to pay for each biome and sum the figures over the biosphere. Since values for each biome include substantial non-market benefits, their technique yields ecosystem values greater than the sum of GDP across nations.

In most of the estimates we develop, the following scenario is posed: suppose that a discriminating monopolist owns all ecological services in the global economy; how much could this monopolist charge humans for using these services? Essen- tially, we wish to investigate maximum dollar values this monopolist could extract if a market were suddenly established for all ecological services. The most liberal estimate is arrived at by assuming that the monopolist extracts all world output, leaving just enough for subsistence. If the world economy produces a gross product of $\$ 18.5$ trillion per year and the world's population is 5.8 billion $^{4}$, per capita world gross product is $\$ 3190$. If minimal subsistence product per capita to sustain the population is $\$ 400$ per year ${ }^{5}$, then the maximum surplus that can be extracted from the human population, while allowing it to (just) sustain itself, is $\$ 2790$ per capita, or $\$ 16.2$ trillion

\footnotetext{
${ }^{4}$ World Bank and United Nations Population Division; dollar amounts are in constant 1987 dollars (The World Bank, 1995).

${ }^{5}$ As a measure of the cost of maintaining a laborer, we use an estimate of the lowest possible cost of fulfilling their protein requirements. This is most cheaply done by consuming some $200 \mathrm{~g}$ of soybeans and $350 \mathrm{~g}$ of wheat. This can be accomplished with $73 \mathrm{~kg}$ of soybeans per year, which in 1987 could be obtained for $<\$ 13$, and $128 \mathrm{~kg}$ of wheat, which could be purchased for $<\$ 29$. Total expenditure clearly must be somewhat above that to provide micro-nutrients, and the prices given are for bulk purchases which require some labor to divide. They do indicate that the very low incomes on which poorest LDCs survive may not be measurement artifacts. It really is possible to subsist on a few hundred dollars per year. Thus, we use a figure of $\$ 400$ per year per capita, which is close to the lowest actual value for per capita GDP. (Ethiopia has the lowest actual dollar figure for per capita income, $\$ 370$, converted to US dollars using purchasing power parity).
} 
globally. We call this amount the 'Maximum Surplus' the monopolist could charge (Table 1).

The remainder of this paper is organized as follows. In Section 2, we estimate the value of ecosystem services captured in compensation to workers. Section 3 presents the parallel calculation for land rents. Section 4 consists of two refinements on the 'Maximum Surplus' calculated above, allowing for the need to replace human and physical capital and the possibility of incomplete market power. For purposes of comparison, Section 5 presents an alternative estimate of the value of ecosystem services captured in wages. All estimates are made using US data, on the (perhaps chauvinistic) grounds that institutional inefficiencies are minimal in the United States. The estimates are then scaled, using either GDP or biomass multipliers, to a global valuation.

\section{Capitalization of wages}

Imagine that the biosphere is owned by a monopolist who can extract all rents ${ }^{6}$, which might otherwise accrue through the labor market to the human population. Assume that labor and ecological services are weak complements in production; the necessity of ecosystem services in the productivity of labor is then reflected by the surpluses currently accruing to the labor force. The estimated ecosystem value using this approach represents an upper bound for the total value of ecosystem services now captured by workers. The estimate is given by Eq. (1):

Ecosystem value + Subsistence wage

$=$ Total wage bill,

where the subsistence wage is taken to be $\$ 400$ per capita per year, as given in the introduction. In 1994, there were 87379000 full-time workers with

\footnotetext{
${ }^{6}$ The term 'rent', as used by economists, refers to the amount paid for a service over the minimum that would have to be paid to attract the resources needed to produce that service. In most examples in this paper, the human population has no alternative employment outside of dealing with the owner of the biosphere, so anything paid to humans above what it takes to keep the workforce reproducing is 'rent'.
}

median weekly wages of $\$ 467^{7}$, and 26050000 part-time workers with median weekly wages of \$385 (US Department of Commerce, Census of the Population, 1995). Assuming each full-time laborer works for 52 weeks per year, annual income for full-time workers is $\$ 24284$, or $\$ 18855$ in 1987 dollars. Subtracting the yearly subsistence value of $\$ 400$ per worker implies that $\$ 1.6$ trillion can be extracted from the full-time work force. Also, if part-time workers cannot be made to work full time (many are performing household services essential to subsistence), $\$ 6622$ can be extracted from each part-time worker, for a total of $\$ 0.2$ trillion. Therefore, the surplus the monopolist could extract from the entire US worker population is $\$ 1.8$ trillion. This figure is scaled to the global level by multiplying it by four, on the grounds that 1987 GDP in the US was $25 \%$ of global gross product. Ecosystem services, as capitalized in the wage bill, are thus estimated at $\$ 7.2$ trillion annually. This is reported in Table 1 as 'Complementary Labor Value'.

\section{Land rent differentials}

In this section we present an estimate of the value of ecosystem services captured in the private land market. We focus on agricultural land, as rents associated with other uses of land are possibly included in the estimate of compensating wage differentials in Section 5. The definition of agricultural land utilized in this section follows that used to designate 'Land in Farms' by the US Department of Commerce, Bureau of Census (1982, 1992), in their Census of Agriculture.

Agricultural production requires that land be combined with other inputs we divide into two categories: man-made inputs and ecological services. Ecological services include soil salinity and permeability, annual rainfall, soil microbes and average temperatures - any attribute naturally occurring in and around land. Man-made inputs

\footnotetext{
${ }^{7}$ Dollar amounts were converted to 1987 dollars for comparability using the GDP deflator reported in the Budget of the United States, Fiscal Year 1997, Historical Tables (US General Accounting Office, 1997).
} 
include fertilizer, machinery and labor, all of which are priced in markets. The land itself is also priced in markets, but ecological services are not. Since ecological services are critical in determining demand and best use for agricultural land, there is likely to be weak complementarity between land and ecosystem services. Given usable data on land prices, we could make a calculation parallel to that made above for labor by subtracting from land prices the amount representing man-made inputs that are sold with land. We do not have such data and therefore use the following alternative scheme.

Agricultural output markets are close to perfectly competitive, so farmers should earn zero rents from production. This implies that the difference between annual gross value (price times output) and total factor payments should be zero. Man-made factor inputs are easily valued since they are priced in private markets. Thus, from the zero-rent assumption, any positive residual value remaining after subtracting market-priced factor payments from the annual gross value of a farm is the total use value of ecological services in agricultural production. Hence:

Ecosystem value + Production expenses

$=$ Value of output,

Production expenses reflect the market value of man-made inputs. We use average per acre expenses of $\$ 135$ per acre ${ }^{8}$ and the value of output for the two top crops in the US to calculate the residual value of ecosystem services in Eq. (2).

\footnotetext{
${ }^{8}$ Expenses included in our calculations include: seeds, bulbs and trees added; commercial fertilizer; other commercial chemicals; machinery hire; feed purchases; hired labor; contract labor; energy and other petroleum products; and interest expenses for farm business. The total value of these expenses is reported in the Census, as is the number of farms incurring each of the expenses. Using these numbers, we compute average expenses per farm as $\$ 61097$ in 1982. Accounting for inflation using the Producer Price Index for farm products, inflation-adjusted average per farm expenses for 1987 are \$63358. Additionally, according to the US Department of Agriculture, the average acreage for a US farm is 469 acres. This information yields the average per acre expenses number used in our calculations.
}

Total corn crops are the highest crop-use percentage of all crops in the US and occupy $15 \%$ of all arable land in the US. ${ }^{9}$ Corn also had the highest value of production of all crops in the United States in 1995. The state with the highest value of yield per acre for corn crops is Iowa, where corn land yields $\$ 291$ per acre. ${ }^{10}$ Subtracting production costs of $\$ 135 /$ acre, the net surplus of corn production in Iowa is $\approx \$ 156 /$ acre. The state with the lowest value yield per acre in corn is Montana, where net surplus is $\$ 145 /$ acre. $^{11}$ Thus, for the 70.29 million acres of corn land in the US, the total value of ecological services is $\approx \$ 10-11$ billion.

The other crop we consider is soybeans, which occupies $\sim 13 \%$ of all arable US land. The state with the highest value of soybean yield per acre in 1995 is again Iowa, where surplus was $\$ 65$ per acre in $1995 .^{12}$ The state with the lowest value of soybean production was Florida, which yielded excess rents close to zero. Approximately 60.6 million acres are devoted to production of soybeans in the US, giving an upper bound valuation of ecological services in the production of soybeans equal to $\$ 4$ billion. Adding this to our estimate for corn, at least $28 \%$ of the arable land in the US benefits from ecological services with a total value of $\$ 14-15$ billion per year.

To scale this number into a global ecological service value for agricultural land, we first multiply by $1 / 0.28$ to estimate an upper bound on the value of ecosystem services enjoyed by all farmers in the US. The resulting figure is multiplied by $1 / 0.07$ to derive the value that could be enjoyed if US farming was extended to the rest of the world. The biomass multiplier, $1 / 0.07$, is obtained via the fact that the US contains $\sim 7 \%$ of the world's

\footnotetext{
${ }^{9}$ CIA World Factbook 1995, (US Central Intelligence Agency, 1995) and US Department of Agriculture, Agricultural Statistics 1995-96 (US Department of Agriculture, 1995-1996).

${ }^{10} 123$ bushels per acre $\times \$ 3.05 /$ bushel (USDA) times the GDP deflator of 0.776 .

${ }^{11} 120$ bushels/acre, $\$ 3.00$ per bushel in 1995 prices.

1243 bushels per acre, $\$ 6.75 /$ bushel in 1995 prices.
} 
continental biomass (Continental biomass is the appropriate measure since the only type of agriculture we consider here is completely landbased). This figure is in turn based on rough measurements of the amount of area covered by each of seven biomes ${ }^{13}$ and the average biomass densities for each biome (Begon et al., 1986). Multiplication by these numbers gives a total value of $\$ 765$ billion.

The last row of Table 1 reports the summation of values captured in wages and land rents and labels this value as 'Total Complementary Value'. There is fear that some ecosystem services have thus been counted twice, but we believe that peril to be minimal. Double counting occurs to the extent that profit of farm owners is counted in wage calculations, but not subtracted as a cost to the farm. This would likely have been a serious problem a century ago, but family farmers are now $<3 \%$ of the labor force. ${ }^{14}$ Further evidence that this potential upward bias is minute is provided by our alternative calculations below, which all yield values well above the total complementary value.

\section{Steady state capital flows}

The maximum surplus suggested in the introduction and calculated by subtracting subsistence income from world product is a surplus that cannot be sustained. Just as it is necessary to feed workers to obtain a full year of output, it is necessary to rebuild capital and train new generations of workers if the stream of output is to be produced in perpetuity. The calculations below are intended to indicate how great a difference this sustainability constraint will make to the total valuation of ecological services.

\footnotetext{
${ }^{13}$ We assume the US contains $\sim 25 \%$ of the world's temperate grassland, $25 \%$ of its temperate deciduous forest, $20 \%$ of its temperate evergreen forests, $11 \%$ of its desert/semidesert regions, $10 \%$ of its swamp and marshlands, $9 \%$ of its cultivated land, and $5 \%$ of its chaparral biome. These assumptions render an estimate that the US contains $\approx 127.1$ metric tons of biomass.

${ }^{14}$ US Department of Commerce, Census of the Population (1995).
}

In the case of a monopolist owner of ecological services, the only subtraction that must be made for physical capital is the cost of building new machines to replace those which wear out or become obsolete. We know of no data series that corresponds to this cost precisely. What we would like is a solution to the problem of maximizing output subject to a sustainability constraint; that is, the requirement that real production is constant in perpetuity. The numbers reported under capital depreciation in GDP (which are intended to capture the amount of capital value lost in routine wear and tear) are more similar to the solution to the problem of minimizing tax burdens subject to a legal constraint. Congress and the Internal Revenue Service determine the fraction of total capital value firms may deduct from pre-tax income for several categories of equipment; firms then choose equipment types with these tax advantages in mind. Actual deterioration of physical capital is approximated only to the extent that the coefficients in the tax-code represent actual rates of wear and tear. Even this imperfect measure is calculated completely only for the manufacturing industry.

Nevertheless, the total annual rate of capital depreciation reported in the 1987 Census of Manufacturers was $\$ 63$ billion (US Department of Commerce, Bureau of Census, 1987). To this we add the cost of capital rented in the accountant's sense, another $\$ 15.6$ billion $^{15}$ to conclude that some $\$ 76.6$ is required to maintain the industrial base. $^{16}$ To calculate from this manufacturing figure, a number for the whole economy, we have only the roughest of techniques. Manufacturing

\footnotetext{
${ }^{15}$ Any piece of capital owned by one manufacturer and rented to another would therefore be double-counted. It seems probable, however, that most rented machinery is owned by firms in the rental business, which falls into the category of services.

${ }^{16}$ This is within $\$ 100$ million of (manufacturers) reported spending on new capital in the same census. This latter figure should include spending dedicated to the expansion, as well as maintenance, of the manufacturing base. But, since the total value of the manufacturing capital stock rose by only $\$ 15$ billion during all of the 1980s (US Department of Commerce, Bureau of Census, 1995 Table 1245), any correction is most likely small.
} 
contributes less than one-third of total US GDP; it is, however, much more capital intensive than service sectors. In keeping with the goal of finding a maximum surplus, we seek the minimum reasonable deduction for depreciation. Doubling the manufacturing number seems an appropriately conservative deduction. Thus, having subtracted from GDP the minimum wage bill and that part of land rents not paying for ecosystem services, we subtract another $\$ 160$ billion to find the maximum surplus.

By way of a consistency check on this number, the total value of industrial machinery and equipment sold in the census year was roughly $\$ 218$ billion, while the total value of transport equipment was $\$ 333$ billion. If all purchased machinery were used domestically to replace worn out equipment, it would imply a deduction four times as great as that calculated from our depreciation figure. Only about $\$ 0.12$ billion worth of this was exported (US Department of Commerce, Bureau of Census, 1995, Statistical Abstract for the US, Table 1255) and the transportation sector appears to be increasing its capital stock at a rate of $\$ 15$ billion per year (US Department of Commerce, Bureau of Census, 1995, Table 875). Since manufacturing expanded very little (US Department of Commerce, Bureau of Census, 1995, Statistical Abstract for the US, Table 1255), the alternative figure should be well above our $\$ 160$ billion estimate. This increases our confidence that the figure is a lower bound on the deduction required for sustainability of the capital stock.

We now turn to sustaining the human capital stock of the economy. The cost of sustenance should include some valuation of the total cost of parental time, some fraction of health care expenditures, production sacrificed to reduce childhood exposure to lead and several tens of thousands of similar items. These are undoubtedly valuable inputs but they are not priced in markets. Thus, we view the stock of human capital as if it were simply a stock of educational attainment. As such, the stock currently consists of 55.7 million high school graduates, 20.8 million holders of bachelors degrees, 7.5 million masters degrees, 2.75 million professional degrees, and 1.2 million doctorates (US Department of Commerce, Bu- reau of Census, 1995 Table 545). The cost of a year of education for a child is $\sim \$ 3600^{17}$, although this would surely be much lower if teachers and administrators were earning subsistence wages (a similar qualification applies to the cost of producing physical capital). We will use this dollar figure for all levels of education.

For our calculations, we assume that a high school graduate must be replaced every 50 years, a college graduate every 44 years, a master or professional every 41 years and a doctorate every 40 years. These assumptions are made by subtracting an estimated age of attainment of these degrees ${ }^{18}$ from the normative retirement age of 68 . Therefore, maintaining the human capital stock requires the creation of 1.15 million high school graduates, 0.47 million college graduates, a quarter million masters and professionals and 30000 doctorates each year. The assumption of constant cost per year of education and the same assumption on the time taken to attain each degree indicates each high school graduate will cost $\$ 47000$; each college graduate $\sim \$ 68000$; each master or professional $\$ 79000$; and each doctorate $\$ 82000$. This yields a human capital replacement bill of $\$ 105.8$ billion per year. Extrapolating these numbers to the rest of the world and subtracting from 'Maximum Surplus', the total required to sustain human and physical capital gives the $\$ 15.9$ trillion reported as 'Maximum Sustainable Surplus', in Table 1. Our conservative estimates of what is required to sustain capital result in only an insignificant reduction in the amount a monopolist could extract from the human population. The more liberal estimate of physical capital needs implied by the total value of equipment sales would reduce this amount by less than onefourth of one percent.

\footnotetext{
${ }^{17}$ US Bureau of the Census 1995, Table 245. Converted to 1987 dollars with the GDP deflator from Budget of the United States, Fiscal Year 1997, Historical Tables (US General Accounting Office, 1997).

${ }^{18} \mathrm{We}$ assume high school can be completed at age 18 and that other degrees can be earned in the average times reported in US Department of Commerce, Bureau of Census (1995), Statistical Abstract of the United States, Tables 295-297.
} 
A further calculation assumes that the services of nature are not purely complementary to other factors of production. If this is the case, the hypothetical owner of ecological services is unlikely to enjoy the complete market power assumed in our previous calculations. To give a rough indication of how much might nonetheless be charged for ecological services, we subtract from the above payments which would have to be made to owners of labor and capital in a market economy. Clearly, these are less than the actual payments made to U.S. workers and owners of capital, which include some of the returns to the unowned environment. As to how much less, we use the following set or rather ad hoc assumptions for demonstrative purposes. Suppose that a typical worker earns the same wage as an Italian worker ${ }^{19}$ and that a capital owner earns $12 \%$ on her resource. Assuming these factors are then used as productively as in the US, owners of nature would collectively earn the amount reported in Table 1 as 'Maximum Sustainable NonMonopolist Surplus'.

\section{Compensating wage differentials}

This section uses results from Blomquist et al. (1988) to estimate a value for ecosystem services that is capitalized in the wage and housing markets. Unlike the results in Table 1, values calculated in this section are for services provided by ecosystems directly to consumers; that is, we are now valuing inputs to consumption rather than production. One might think, therefore, that these estimates should be added to the numbers derived so far to find a total value for ecosystem services, but that would be erroneous - values to households are conditional on household income, which includes excess rents due to ecosystem services. Our purpose in presenting these numbers is merely to indicate the likely relative importance of these non-market ecosystem benefits.

The techniques used here are due to Rosen (1979), who suggested that locations are best

\footnotetext{
${ }^{19}$ About $\$ 15800$ per year, according to Reddy (1994), p. 457.
}

viewed as tied bundles of wages, rents and amenities. More recently, evidence of the influence of amenities on wages has been researched by Roback (1982), Graves (1983) and Blomquist et al. (1988), amongst others. Their findings suggest that wages are negatively affected by positive amenities and positively affected by negative amenities (workers are generally willing to give up higher wages to live in more amenity-rich regions). ${ }^{20}$

Amenities and disamenities in the Blomquist et al. (1988) study, that we assume are ecological services, include average precipitation per year, humidity, heating degree days per year, cooling degree days per year, average wind speed (miles per hour), sunshine (days per year), and proximity to coast. Blomquist et al. (1988) found that precipitation, sunshine and access to the coast are marginal net amenities - that is, the wage differential in the presence of these ecological factors is negative, implying workers are willing to accept lower wages to live in regions with greater access to these amenities. Humidity, heating degree days, cooling degree days and wind speed are found to be marginal net disamenities. Workers in regions with greater amounts of these disamenities will receive higher wages, ceteris paribus.

An upper bound can be obtained by assuming one US county represents 'Nirvana', which is characterized by the 'best' bundle of ecological amenities/disamenities found in Blomquist et al. (1988). Nirvana would then be characterized by having access to the coast, healthy annual precipitation, higher-than-average days of sunshine, low wind speed, lower-than-average heating and cooling degree days and low humidity. Similarly, we construct a fictional county with the worst possible amenity/disamenity bundle ('Low County') and one with the mean level of every amenity and

\footnotetext{
${ }^{20}$ An anonymous referee pointed out that the value of a given amenity will vary across people; and it may even be the case that one person's amenity is another's disamenity. This point is correct, but we may nonetheless speak unambiguously of the value of an amenity as its value to the person who values it most - that is, the agent who would own the amenity if the amenity were marketed. This same problem applies to conventional private goods and the same solution was found by the classical economists (Jevons, 1879; Walras, 1831).
} 
disamenity ('Average County'). The housingprice-corrected wage differential between 'Nirvana' and 'Low' County can be calculated for an upper bound estimate of amenity services to the average household. A more conservative estimate is given by the equivalent differential between Nirvana and Average County. These valuations are summed across laborers to estimate the total value of US ecosystem amenity services to US workers.

Full implicit prices for various amenities in Nirvana, Average, and Low counties are reported in Table 2. ${ }^{21}$ These data are given in 1987 dollars. Positive values represent a marginal net amenity, while negative values represent a marginal net disamenity. Values should be interpreted as follows: those living in the county with the most wind (Low County) are compensated $\$ 863$ implicitly in the labor and housing market over those living in the county with the lowest wind speed (Nirvana County). It could also be said that $\$ 658$ is capitalized in wage and housing values in Nirvana due to its proximity to the coast; or, more succinctly, residents in Nirvana give up $\$ 658$ per year to have access to a coast.

Nirvana's implicit valuation of all ecosystem services is calculated by summing amenity values.

Table 2

Comparison of amenity values across counties

\begin{tabular}{lrrr}
\hline Amenity & Nirvana & Average & \multicolumn{1}{l}{ Low } \\
\hline Precipitation (\$) & 1211 & 1135 & 123 \\
Humidity (\$) & -1923 & -4198 & -4732 \\
Heating degree days & 23 & -520 & -1096 \\
$\quad(\$)$ & & & \\
Cooling degree days & 28 & -630 & -2053 \\
$\quad(\$)$ & & & \\
Wind speed (\$) & -836 & -1239 & -1669 \\
Sunshine (\$) & 5863 & 4116 & 3068 \\
Coast (\$) & 658 & 148 & 0 \\
\end{tabular}

${ }^{21}$ Using Blomquist et al.'s, 1988 regression coefficients, an estimate of the full implicit price of amenities can be obtained. We first multiply the housing coefficients by 12 (months per year). For the wage coefficients, we multiply these by the sample mean of workers per household (1.54), mean hours worked per week (37.85) and mean weeks worked per year (42.79) (Blomquist et al. (1988), p. 95).
This process yields an implicit value of $\$ 4922$, which can be multiplied by the number of fulltime workers to yield a total value of $\$ 0.4$ trillion. Alternately, multiplying by the total number of workers (full-time and part-time) yields an estimate of $\$ 0.6$ trillion. Scaling the full workforce number to a global value (using the GDP multiplier of four) yields a total global value of $\$ 2.4$ trillion.

To get a sense of how much better off Nirvana County is than Low County, we calculate differentials across these counties. Subtracting Nirvana's column sum from Low's gives an estimate of how much income Nirvanans forego to live in their county. Using the above data, we calculate this differential as \$11311. Multiplying this figure by the number of full-time workers yields a total value of $\sim \$ 1$ trillion. Using the entire workforce, full-time and part-time, yields a total value of $\$ 1.3$ trillion. Scaling this to a global figure yields a total value estimate of $\$ 5.2$ trillion.

This same technique can be applied to garner a more conservative estimate. Making a comparison between Nirvana and Average County reveals a differential of $\$ 6,110$. Multiplying this figure by the number of full-time workers yields a more conservative estimate of $\$ 0.5$ trillion for the total value of ecosystem services. If instead we use the total number of workers, we find the total value to be $\$ 0.7$ trillion. Using, once again, the GDP multiplier, we compute the total value of ecological services as $\$ 2.8$ trillion.

\section{Conclusions}

In this paper we have presented several approaches to estimate the value of ecological services in global production. Our purpose is to present some economically logical valuations for the ecosystem that might be included in future green GDP accounts. Most of our estimates are based on the assumption that a monopolist owner of the ecosystem establishes a market for its resource and begins charging the population for its use. In the most extreme case, this monopolist could theoretically charge the global population an amount that would just allow continued sub- 
sistence. If the ecosystem is purely complementary to other factors of production, the monopolist could extract all excess rents currently accruing to owners of the other factors.

We also incorporate a sustainability constraint into our estimates, allowing capital stocks to be replenished over time. The resulting figures are much lower than those calculated above, but appear to be more reasonable given capital stocks probably have to be replenished over time to maintain sustainable production. In addition to investigating these 'maximum surplus' and 'complementary value' estimates, we also explore the value of ecosystem services using compensating wage differential data and a non-monopolist rents assumption in order to obtain more conservative estimates. All of these estimates are bounded logically by zero on the lower end and gross world output at the upper end. Our estimates suggest that ecological services are worth between 44 and $88 \%$ of total world output.

Although our findings are much lower than estimates found by Costanza et al. (1997), the underlying message is clearly similar-including the value of the ecosystem would dramatically alter current GDP estimates. Our approach differs from concepts more frequently endorsed in green GDP accounting, such as inclusion of 'depreciation' or depletion of natural resource stocks, in that it calls direct attention to the productive contribution of ecosystem services as a whole. Nevertheless, results from our numerous estimation techniques emphasize the importance of inclusion of the ecosystem in current GDP accounts.

\section{Acknowledgements}

We wish to thank Robert Costanza, participants at the University of California-Santa Barbara National Center for Ecological Analysis workshop, 'The Total Value of the World's Ecosystem Services and Natural Capital', and three anonymous referees for their helpful com- ments on previous drafts. All remaining errors are the sole responsibility of the authors.

\section{References}

Begon, M., Harper, J.L, Townsend, C.R., 1986. Ecology: Individuals, Populations, \& Communities, 1. Blackwell, Boston.

Blomquist, G., Berger, M., Hoehn, J., 1988. New Estimates of the Quality of Life in Urban Areas. Am. Econ. Rev. 78, 89- 107.

Brown, T., 1984. The Concept of Value in Resource Allocation. Land Econ. 60, 1-23.

Costanza, R., d'Arge, R., de Groot, R., Farber, S., Grasso, M., Hannon, B., Limburg, K., Naeem, S., O’Neill, R., Paruelo, J., Raskin, R., Sutton, P., van den Belt, M., 1997. The value of the world's ecosystem services and natural capital. Nature 387, 253-260.

Graves, P.E., 1983. Migration with a composite commodity: The role of rents. J. Reg. Sci. 23, 541-546.

Jevons, W.S., 1879. The Theory of Political Economy. Macmillan, London.

Mäler, K.G., Gren, I., Folke, C., 1994. Multiple use of environmental resources: A household production function approach to valuing natural capital. In: Jansson, A., et al. (Eds.), Investing in Natural Capital: The Ecological Economics Approach to Sustainability. Island Press, Washington, DC, pp. 233-249.

Reddy, Marlita A. (Ed.), 1994. Statistical Abstract of the World. Gale Research. Detroit.

Roback, J., 1982. Wages, rents the quality of life. J. Polit. Econ. 90, 1257-1278.

Rosen, S., 1979. Wage-based indexes of urban quality of life. In: Miezkowski, P., Straszheim, M. (Eds.), Current Issues in Urban Economics. John Hopkins Press, Baltimore, MD, pp. 74-104.

US Central Intelligence Agency, 1995. C.I.A. World Factbook.

US Department of Agriculture, 1995-1996. Agricultural Statistics.

US Department of Commerce, Bureau of Census, 1982, 1992. Census of Agriculture.

US Department of Commerce, Bureau of Census, 1987. Census of Manufacturers.

US Department of Commerce, Bureau of Census, 1995. Census of the Population.

US Department of Commerce, Bureau of Census, 1995. Statistical Abstract of the United States.

US General Accounting Office, 1997. Budget of the United States, Fiscal Year 1997, Historical Tables.

Walras, A.A., 1831. De la nature de la richesse et de l'origine de la valeur. Johanneau, Paris.

The World Bank, 1995. World Bank Atlas. 